\title{
DA OBRA DE ARTE TOTAL À SÍNTESE DAS ARTES
}

\author{
Marcos Faccioli Gabriel ${ }^{1}$
}

\begin{abstract}
Resumo: Houve, durante o século XX, uma persistente recorrência do tema da síntese ou integraçáo das artes, em especial no campo da arquitetura: desde as vanguardas dos anos de 1920 até a ressurgência do tema, no imediato Pós-II Guerra, com Le Corbusier, Sigfried Giedion e Fernand Léger. No Brasil, nos anos de 1950, o entusiasmo de Mário Pedrosa com a construção da nova capital seguiu o lema Brasilia, a cidade nova, sintese das artes (1981b, p. 355-363). A literatura correspondente menciona com frequência os nomes do arquiteto Gottfried Semper, um teórico oitocentista do estilo, e sua cooperação com o compositor Richard Wagner. O interesse contemporâneo pelo tema da síntese ou integração das artes e suas relaçóes com arte e arquitetura aponta para os trabalhos desses dois autores como a proposição inicial, no âmbito da Gesamtkunstwerk ou a obra de arte total. Neste estudo, examina-se a feiçấo especulativa com que Wagner sustentou a Gesamtkunstwerk, como passo estratégico para os estudos sobre o tema.
\end{abstract}

PalaVras-chave: Gesamtkunstwerk. Síntese das artes. Integração das artes. Teoria da arquitetura. Vanguardas históricas.

\section{INTRODUÇÃo}

A maior personalidade do séc. XX a ter o nome associado pelo público à síntese ou integração das artes talvez tenha sido Le Corbusier. Já nos tempos de Le sprit nouveau, concebia uma "síntese das artes maiores" (CALATRAVA, 2010), em que urbanismo, arquitetura e artes plásticas se ergueriam sobre a base constituída pela beleza mecânica ou estética do engenheiro, de tal modo que diversas produçôes, diferentes em escala e hierarquia expressiva, fariam da totalidade ambiental da Ville radieuse a realização do espírito e do

\footnotetext{
${ }^{1}$ Professor de Teoria e História no curso de Arquitetura e Urbanismo da Faculdade de Ciência e Tecnologia da Universidade Estadual Paulista (Unesp), Presidente Prudente, SP - Brasil. (D) http:// orcid.org/0000-0002-0802-0896 Email: m.gbr@uol.com.br
}

http://doi.org/10.1590/0101-3173.2020.v43n2.11.p189

\section{(i)}


lirismo, no mundo moderno (LE CORBUSIER, 1923, p. 10). Nos anos do pós-guerra e durante toda a década de 1950, Le Corbusier apresentou nova e mais apaixonada versão da síntese das artes, como um antídoto aos horrores da guerra recém-terminada e um impulso necessário aos tempos da reconstrução.

O fundamento da síntese estaria (CALATRAVA, 2010) na compreensão do destino da civilização que tinha o grande arquiteto, e na sua concepção de dualidades a dominar em todas as escalas, uma oposição de contrários a cindir o terreno de onde, os textos sugerem (LE CORBUSIER, 1923, 1924), surgiriam as guerras. A síntese passaria por superar os conflitos entre as especialidades do saber, sempre em número crescente, na modernidade, e encontrar-lhes a complementaridade e a colaboração. Daí a importância que o tato e a audição adquiriam, nas justificações de suas obras, contra o privilégio abusivo da visão, na cultura ocidental, de que surgiam questóes como a "acústica plástica", o "escutar a música do mundo", o "integrar a música na arquitetura”. A síntese operaria uma recuperação da origem comum poética das artes maiores, numa "nova unidade ancestral e moderna".

Em 1943, o historiador da arquitetura Sigfried Giedion, junto com Fernand Léger e com o urbanista Josep Luís Sert, publicou o manifesto Nine points for a new monumentality (GIEDION; SERT; LÉGER, 1993, p. 29-30), no qual clamavam pelo retorno da arquitetura obra de arte, após a interrupção pelo que Mário Pedrosa (1981a) chamou de "a terrível dieta funcionalista”. O que surpreende um leitor de nossos dias é que aquele manifesto representava esse clamor como um anseio dos povos por arquitetura-arte, a qual expressasse os laços constituintes das comunidades que, se esperava, formariam o tecido social das cidades reconstruídas ou das novas cidades. Havia, ao que nos parece, uma crença já bastante datada numa sinergia entre a arte moderna e as novas formas de sociabilidade que, se acreditava, surgiriam após a guerra. Haveria uma síntese entre as novas formas de sociabilidade e as novas formas artísticas que superassem as artes individualistas e se apossassem de novos meios técnicos de expressão, tornando possíveis espetáculos de luzes, cores e águas, animando longas fachadas urbanas modernas. Os autores evocavam grandes festividades urbanas modernas e lhes atribuíam algo como o espírito dos festivais dramáticos da antiguidade grega.

Mário Pedrosa (1981b, p. 355-363) aderiu entusiasticamente à construção de Brasília e elaborou a ideia da Nova Capital com similaridades. Brasília, "A cidade nova, síntese das artes", seria uma "obra de arte coletiva", na qual atingir finalidades coletivas iria de par com a mais ampla aspiração à 
síntese, cuja contraparte era o "pessimismo destrutivo da arte individualista de nossos dias, [os] impulsos temperamentais românticos e expressionistas em voga" (PEDROSA, 1981b, p. 361). Pedrosa imaginava uma reconstrução do mundo com a técnica moderna aplicada à construção de cidades modernas em bases comunitárias; e uma integração entre urbanismo, arquitetura e artes plásticas que mudaria as condiçóes do juízo das obras mesmas: "A obra em si de um artista não pode mais ser examinada por ela mesma. [...], mas é dentro do contexto ambiental que todas as artes e atividades correlatas podem encontrar o momento crucial de sua integração, quer dizer, de sua autêntica realização no complexo social" (PEDROSA, 1975, p. 216).

Imaginar o ambiente moderno construído com certa aparência artística é uma ambição que lembra os velhos estilos ou, pelo menos, dava concretude ao que Pedrosa (1964, p. 212) chamava de estilo de nossa época. Este seria uma síntese universal social-artística tornada possível, porque a nova tecnologia industrial, supostamente, já se teria desenvolvido a ponto de fazer com que as velhas utopias se tornassem problemas de projeto.

Através dessas personalidades e de seus sonhos, flagramos, no modernismo nas artes e na arquitetura nos anos de 1950, a ressurgência de alguns temas presentes já no surgimento do "movimento moderno em arquitetura”, ou seja, a síntese ou integração das artes como a realização do "estilo da modernidade" (BANHAM, 1970, p. 320-330), aliás dois temas estreitamente ligados, se é que não eram um único. O tema do estilo da modernidade como um problema de projeto surgiu na história da arquitetura, até onde se sabe hoje, com o arquiteto e teórico Heinrich Hübsch (17951863), o qual, desde 1828, veio a público dar-se conta da inviabilidade tanto do historicismo quanto do ecletismo, para criar algo como um estilo da modernidade e lançar algumas bases - ou interrogaçóes - de um suposto novo estilo. $\mathrm{O}$ apelo de Hübsch deu origem a um ciclo de debates no âmbito alemão, entre 1830 e 1850, no qual não estivera ausente Gottfried Semper (1803-1879), nos anos de 1840 a 1849 , que mais tarde viria a desenvolver a primeira teoria moderna do estilo, o monumental Estilo nas artes tectônicas e técnicas: uma estética prática (SEMPER, 2004).

Entretanto, a primeira aparição da ideia da Gesamtkunstwerk se deu, segundo a literatura, com o filósofo Eusebius Trahndorff (1783-1863), em seu trabalho Ästhetik oder Lehre von der Weltanschauung und Kunst ${ }^{2}$ (1827), autor muito pouco conhecido entre nós. A formulação de Wagner (1813-

\footnotetext{
${ }^{2}$ Estética do estudo das visóes de mundo e da arte.
} 
1883), compositor e reformador do gênero operístico, ocorreu no âmbito cultural do teatro, mas com uma formulação especulativa e pretensão a um conceito geral, a saber: a obra de arte que reúne todos os gêneros ou meios expressivos e transcende a condição histórica na qual prevalece a separação egoísta dos "ofícios artísticos". Consoante, Wagner, ressentindo-se de que a ópera de seu tempo fosse uma sequência de números virtuosísticos, conforme as ambições de carreira de solistas e com o gosto do público usuário filisteu, empreendeu a criação de seus "dramas sinfônicos". Essa multiplicidade de manifestaçóes, contudo, as quais, de um modo ou de outro, aparecem como relacionáveis à Gesamtkunstwerk, é francamente desanimadora e torna oportuno para a historiografia explorar o denominador comum a todas elas, o desenvolvimento especulativo que Wagner imprimiu à Gesamtkunstwerk, o que será nosso objetivo aqui em alguns de seus traços.

\section{Grandeza e ruína da tragédia na GréCia}

Em 1842, o jovem Richard Wagner chegou a Dresden com a intenção de ali estabelecer uma reputação artística e passou a frequentar os círculos intelectuais daquela cidade, onde travou uma amizade de intenso debate de ideias com Gottfried Semper. Este último, arquiteto, teórico e historiador, teve uma juventude rebelde e aventureira, com cursos superiores frequentados de modo intermitente, longas temporadas na Itália e em pesquisa arqueológica na Grécia, ao fim das quais apareceu com o estudo que primeiro o projetaria: Observaçóes Preliminares sobre a Arquitetura e a Escultura Policromadas da Antiguidade (1989a). Esse trabalho lhe valeu indicação de Karl Friedrich Schinkel, através da qual se tornou professor na Kunstakademie de Dresden, em 1841.

Essa época de suas vidas, contudo, chegou ao fim nos anos de 1848 e 1849, quando o movimento de conotaçóes radicais pela unificação alemã levou o monarca prussiano a abdicar da coroa, da constituição e do plano de unificação da Alemanha, produzido pelo Bundestag eleito, ou Assembleia Nacional, a fim de esvaziar os protestos violentos em várias partes do país. A monarquia prussiana náo queria de forma alguma que a unificação alemã se desse sob o movimento radical e democrático de então, motivo pelo qual outros vinte e dois anos se passariam, até que a casa se arrumasse, por assim dizer, para a unificaçáo alemá. Naqueles momentos tumultuados de 1848, a certa altura, o monarca da Saxônia sentiu-se politicamente desconfortável 
e quis deixar a capital Dresden e, para tanto, pediu assistência ao monarca prussiano, o qual enviou tropas para confrontação armada com o Landtag (Assembleia Estadual) saxão. Do confronto entre insurgentes pró-unificação e as tropas prussianas, resultaram centenas de mortos, prisioneiros e outros tantos forçados ao exílio, entre os quais Semper e Wagner (MALLGRAVE, 2004, p. 9). Wagner cumpriria exílio na Suíça, entre 1849 e 1858.

Dentre os textos de Wagner, Arte e revolução e $A$ obra de arte do futuro mostram suficientemente, para nossos fins, o sentido de sua proposição da Gesamtkunstwerk. Ambos foram escritos em 1849, logo após o fracasso da revolta de Dresden. No primeiro deles, dá-se a constatação de um mal-estar bem moderno: os artistas tornaram-se filisteus servidores do comércio e a arte havia decaído à esfera do luxo para consumo das elites. Esse mal-estar diz algo que singulariza a modernidade, pois, em outras épocas, pouca gente teorizava sobre o fato de que os refinos da arte fossem encontrados apenas em templos, edifícios públicos e residências principescas. A suspeita de que os artistas fossem filisteus, contudo, não era nem um pouco nova. Os gregos antigos consideravam-nos indignos da condição de homens livres por fazerem comércio com a produção de objetos belos (ARENDT, 1977, p, 194-222) e não pelo modo como se dava o uso daqueles mesmos objetos. Mas por que a modernidade, com Wagner, se punha nessa direção tão energicamente? Por que um mal-estar tão grande com o suposto caráter filisteu dos artistas e a reação para promovê-los a um papel civilizatório tão desproporcionalmente elevado se dava no âmbito da Gesamtkunstwerk?

Bem entendido, esse diagnóstico do compositor, de certa maneira, repetia Hegel quando este se dava conta (HEGEL, 1996, p. 19, 25, 26, ) de que a arte, no que concernia a seu destino mais elevado, havia se tornado coisa do passado. Porém, ao contrário de Wagner, Hegel aceitava de bom grado, e até mesmo aplaudia, que o coração dos homens já houvesse esfriado para o belo e que suas mentes se tivessem voltado para ideias e normas universais, pois o espírito, no passo moderno de seu devir, já não se fazia presente através de representações sensíveis, mostrando-se, antes, no meio abstrato. Conforme ele mesmo, a própria arte já nada presentificava de modo imediato e tornara-se dependente da mediação de ideias abstratas, como a requerer exegese.

Wagner seguia de perto o diagnóstico hegeliano, mas o formulava segundo um ponto de vista diverso. Reprovava aos artistas de seu tempo reclamarem das revoluçóes de meados do século XIX, porque lhes interrompiam os negócios, e afirmava que a arte tinha sua vocação e seu sentido mais profundo 
orientados para o universalismo, o qual se manifestava, de uma forma ou de outra, naquelas mesmas revoluçóes, aliás, momentos ou passos da "revolução da humanidade". Essa tese deixava de determinar a relação entre as várias e conflituosas finalidades humanas ou nem mesmo advertia sobre a necessidade de fazê-lo. Mas o mal-estar era-lhe tanto maior, quanto mais acreditava que o amor ao belo entre os antigos gregos era isento do interesse pelo ganho mercantil, o qual, a seu juízo, seria o oposto mesmo do universalismo.

No coração das artes da Grécia antiga estaria, segundo o compositor, o espetáculo teatral da tragédia, no qual se tornava presente, para os sentidos, o espírito da religião e do povo, cujo conteúdo último era a contemplação da necessidade como força vital a impelir o devir temporal:

Aquela era a obra de arte grega, aquele era seu deus Apolo encarnado numa arte viva. Aquele era o povo na sua mais alta verdade e beleza. [...] Sempre alerta, incansavelmente a repelir toda influência externa, o grego não concedia nem mesmo aos costumes ancestrais o direito de dispor de sua vida mundana livre, de suas açóes, e de seus pensamentos. Aos apelos do coro, porém, emudecia, fazia-se escravo solícito daquele espetáculo. Deixava-se conduzir para a grande estória da necessidade cantada pelos poetas trágicos na voz dos deuses e heróis. Na tragédia, pois, ele reencontrava o seu melhor, sua própria natureza unida ao nobre caráter da nação. Naquele palco, como do fundo da alma, como se dela mesma procedesse, a Pitonisa oracular lançava proclamaçóes (WAGNER, 1892a, p. 33-34).

A grandeza daquele povo, do qual Apolo seria a síntese em ato, consistia em ter reunido liberdade individual e espírito comunitário do modo mais perfeito, isto é, a máxima pluralidade de indivíduos e destinos e a mais sólida comunidade, a qual se baseava não em laços de privação e de dependência, porém, numa vida orientada ao público em que não havia lugar para os deleites egoístas da vida privada. $\mathrm{O}$ amor daquele povo pelo belo teria sido isento do ganho e do filistinismo, e sua expressão na tragédia havia sido obra de uma ação comum sob uma mesma ideia. Com a ruína da pólis e o fim da tragédia, separaram-se as artes contribuintes daquele espetáculo, desde entáo rebaixadas ao que Wagner compreendia como os "ofícios artísticos" que a tradição nos legara: literatura, arquitetura, música etc.

Mas qual, segundo o compositor, teria sido a razão daquela ruína? Nenhuma outra senão o pecado de uma comunidade de homens livres que se sustentava materialmente pelo trabalho escravo. Seu universalismo - estreito 
e limitado, pois reconhecia nos homens senhores e escravos - havia sido precipitado na dissolução pelo início da própria "revolução da humanidade", quando, sob a liderança de Péricles, a pólis ateniense estendeu os direitos políticos a artesãos e mercadores, classes estas que produziam para ganho egoísta. A vitória dos revolucionários Péricles e Sófocles contra o conservador Ésquilo, nas palavras de Wagner, teria, paradoxalmente, precipitado a dissolução dos laços comunitários, lançando o ocidente na escravidão universal com o império romano, o qual viria, por sua vez, a dar lugar a uma religiáo da renúncia e da negação da vida: o cristianismo. Para ele,

[...] quando não é possível a todos serem igualmente livres e felizes, todos devem sofrer como escravos. [...] Deveríamos nós, modernos, porque compreendemos a causa da ruína da Grécia trágica, aprender a amar a todos os homens antes de sermos capazes de amar a nós mesmos, antes de redescobrir prazer autêntico com nossa própria personalidade (WAGNER,1892a, p. 51-54).

\section{UM MILENARISMO DA MODERNIDADE}

A grande arte trágica grega teria sido conservadora, porque ela existiu no ambiente fechado da pólis, a qual controlava e se protegia da influência do filisteu e do estrangeiro, os bárbaros ,enfim. O renascimento da grande arte da tragédia que, segundo acreditava Wagner, se anunciava com o universalismo moderno, seria, pelo contrário, revolucionário:

Somente a grande revolução da humanidade, cujos começos esmagaram a tragédia grega, poderá restituir-nos a obra de arte, somente esta revolução poderá resgatar de profundezas ocultas a beleza nova de um universalismo mais nobre, aquilo, pois, que um dia ela arrebatou ao espírito conservador de um tempo e de uma cultura belos, mas estreitos (WAGNER,1892a, p. 53).

Esses escritos dirigiam-se a um futuro e ao fecho de uma era histórica em que a modernidade se singularizava, tanto pelo seu universalismo inédito quanto por seu mal-estar no campo das artes. Esse enfrentamento interrogativo do mal-estar, porém, não especificava ainda um programa de açáo, mas a esperança numa total reversão do curso da história precedente, ou seja, uma autêntica esperança de salvação secular ${ }^{3}$, mutatis mutandis, análoga

\footnotetext{
${ }^{3}$ Hannah Arendt (1999) desenvolve esse argumento, através de suas categorias da atividade humana. A modernidade, com a ciência galileana e com a revoluçáo industrial, teria visto as atividades produtivas
} 
àquela no centro do milenarismo cristão medieval. No entanto, como e de onde viria o impulso que tornaria possível, na modernidade, essa "revolução da humanidade"?

$\mathrm{Na}$ marcha desumana da civilização, contudo, um radioso dia se avizinha: o peso enorme com que a civilizaçáo aplastra a natureza crescerá tanto que um dia lhe conferirá o impulso reativo de lançar fora toda a ganga, a ela, a desprezada, mas sempre viva natureza. Este acúmulo sem fim de civilização terá, então, ensinado à natureza sua própria força titânica. A liberação dessa força será a revolução. [...]. Tão logo a irmandade humana tiver se livrado do cuidado com a manutençáo da vida e, assim como o faziam os gregos que o deixavam com os escravos, o tiver deixado ao maquinário, afinal escravo artificial do homem livre e criativo, então, toda a força humana por si mesma legitimada, será proclamada nada menos que impulso artístico. [...] Quando a manutenção da vida não mais for o objetivo exclusivo da vida $[\ldots]$ e a indústria não for mais nossa amante, mas nossa serva [...] todo homem será, enfim, em um domínio ou outro, um verdadeiro artista (WAGNER,1892a, p. 55, 57-58).

Ora, esta última passagem deixa claro que o impulso realizador da "revolução da humanidade", a salvação secular moderna, teria como condição de possibilidade nada menos do que as forças produtivas da ciência, da indústria e do capitalismo. Isso situava o radicalismo de Wagner dos anos de 1848 e 1849 no campo comum aos socialistas, quer utópicos, quer "científicos". No fundo, sua esperança, como a desses todos, era dirigida à modernidade industrial, esperança de redenção da pena do trabalho e das desigualdades pela técnica desenvolvida. Sua esperança se determinava, contudo, como um programa estético revolucionário, ou reformista que fosse, que de algum modo completasse algo cuja falta a modernidade industrial, em seu movimento automático, não poderia, por si mesma, realizar.

Para que se tenha um vislumbre dos fundamentos comuns a todas as propostas de revolução estética modernas, vale a pena aproximar a de Wagner, que evocava sua construção do drama trágico grego, a um estudo recente sobre os projetos de reforma do teatro moderno, O espectador emancipado, de Jacques Rancière (2012, p. 11):

deslocarem a ação como as mais importantes da sociabilidade. Dentre as atividades produtivas, o homo faber $\mathrm{e}$ o animal laborans, este último, produtor dos meios de mera reproduçáo da vida, tomou a dianteira e predominou completamente. Essa atividade, a qual não deixa rastro ou permanência atrás de si, teria levado, no contexto da modernidade, ao processo ininterrupto de produção que gera mais produçáo, um poder produtivo que, por sua vez, teria inspirado o sonho de abolição da necessidade do trabalho. 
O teatro, mais do que qualquer arte, foi associado à ideia romântica de revolução estética, não já no sentido de mudar a mecânica do Estado e das leis, mas sim as formas sensíveis da experiência humana. Reforma do teatro significava então restauraçáo de sua natureza de assembleia ou de cerimônia da comunidade.

Segundo Wagner, como vimos antes, o espetáculo teatral trágico seria o lugar por excelência da constituição estética e imediata da comunidade, na Grécia antiga pelo menos. Já Rancière expóe como a questáo foi tratada pelos românticos em geral: "Entenda-se a comunidade como maneira de ocupar um lugar e um tempo, como o corpo em ato oposto ao simples aparato das leis, um conjunto de percepçóes, gestos e atitudes que precede e pré-forma as leis e instituiçóes políticas" (RANCIÈRE, 2012, p. 11).

A constituição estética da comunidade ou do povo, no teatro, conduzia Wagner a afirmar a primazia da tragédia sobre todas as outras formas artísticas, bem como a precedência da arte em geral, que seria mais originária em relação a todas as outras formas de conhecimento, à base, vale lembrar, de esperanças milenaristas na modernização científica e industrial. Era como se a condição original e primeira do homem pudesse viver novamente no mais moderno dos mundos. Assim, a superioridade das leis, do Estado, da religião, da filosofia e da ciência sobre a comunidade representava-lhe um estado contrário à natureza humana, uma corrupção necessária talvez, mas a ter um fim, o qual se anunciava com o universalismo moderno e com sua contraparte, a modernização produtiva.

A modernidade estava em causa em sua exegese da tragédia grega, porém, a questão ultrapassou em muito a Wagner e deixou uma marca considerável no séc. XX, e talvez até hoje. Segundo Rancière (2012), os projetos de reforma do teatro de Brecht e Artaud pretenderam levar o espetáculo teatral à supressão de si mesmo, à "restauração de sua natureza de assembleia ou de cerimônia da comunidade", à superação de sua particularidade técnica enquanto espetáculo:

O espetáculo é o reino da visão, e a visão é exterioridade, ou seja, o desapossamento de si. A doença do espectador pode resumir-se numa fórmula breve: 'quanto mais ele contempla, menos ele é. [...] A separação é o alfa e o ômega do espetáculo' [Rancière cita Guy Debord]. O que o homem contempla no espetáculo é a atividade que lhe foi subtraída, é sua 
própria essência, que se tornou estranha, voltada contra ele, organizadora de um mundo coletivo cuja realidade é a realidade desse desapossamento. [...] Em ambos os casos [Brecht e Artaud], o teatro apresenta-se como mediação orientada para sua própria supressão (RANCIÈRE, 2012. p. 12-13).

Wagner concebia, com otimismo, que sendo o homem naturalmente bom e que o mal fosse uma corrupção temporária, deveria haver uma reconciliação possível e necessária entre aparência e verdade, entre necessidade e satisfação, entre indivíduo e comunidade, entre felicidade e virtude. Aliás, seria como um retorno à unidade das partes polares que se haviam separado, no devir histórico. Haveria, portanto, uma medida verdadeira da necessidade, ou seja, a necessidade como força vital a impelir o devir, medida esta que propiciaria uma passagem dos prazeres sensíveis à contemplação da necessidade, medida verdadeira da necessidade que era a comunidade ou o povo:

O povo é o coletivo de todos aqueles indivíduos que sentem uma necessidade coletiva, ou melhor, todos aqueles que reconhecem sua necessidade individual como uma necessidade coletiva. Esta necessidade coletiva é uma verdadeira necessidade (WAGNER, 1892b, p. 75).

Essa verdadeira necessidade, cuja medida era a coincidência da necessidade individual com a coletiva, excluía os extremos de excesso e de falta - nem acúmulo de carência sem satisfação, nem acúmulo de satisfação sem necessidade - ou seja, de miséria e de luxo respectivamente. Assim, "[...] só uma verdadeira necessidade tem direito à satisfação", pois "a falsa necessidade não dá origem a um contrário que lhe seja a antítese. Por isso, uma falsa carência [o luxo] não encontra satisfação" (WAGNER, 1892b, p. 75-76). Tenhamos em mente que essa formulação especulativa de uma reconciliação do homem com sua própria natureza tinha como condição de possibilidade o desenvolvimento das forças produtivas da indústria moderna, algo que Wagner abordava, nas páginas iniciais de seu Arte e revolução (WAGNER, 1892a).

\section{A HISTÓRIA REPETE A NATUREZA}

A noção de necessidade, tão central ao pensamento de Wagner, cobre tanto o ser por essência, ou seja, o que pode ser somente de um modo e de nenhum outro, como a de carência. Ambas as acepçóes expressam uma 
compulsão ou um impulso a ser e a agir de forma determinada, quer por efeito de causa exterior, quer por efeito do instinto.

A cosmologia que Wagner (1892b, p. 69-90) apresentava punha a pergunta sobre a razão da separação entre as partes polares, as quais sofreriam de um modo ou de outro a compulsão a se juntarem na satisfação, como os amantes. A separação surgiria da própria substância, quer dizer, do composto necessidade/matéria, cujo movimento se daria em direção à máxima variedade e pluralidade, movimento no decorrer do qual a necessidade padeceria de uma impotência temporária em face da superabundância da matéria. Essa impotência temporária da necessidade para efetuar o encontro seria revertida, à medida que o acúmulo de insatisfação, por fim, desatasse reativamente a satisfaçáo como potência acumulada que, vencida uma resistência, revertia a ato de um só golpe ${ }^{4}$.

Após tantas fases de expansiva diferenciação, a natureza teria encontrado uma harmonia ou uma estabilidade maximamente diferenciada pela qual, sendo a medida perfeita de todas as coisas, veio também a ser reconhecida pelas artes como seu modelo. Foi quando teve início a história humana, pela qual a necessidade, inconsciente na natureza, se tornava consciente e, dessa forma, a história humana teria como fim, na expressão de Wagner, o "comunismo" 5 (Kommunismus): a unidade entre a máxima pluralidade de indivíduos e a comunidade universal, quando carência e luxo se cancelassem mutuamente, na necessidade satisfeita e na comunidade realizada.

O universalismo ou o "comunismo" de Wagner previa a realização futura - em analogia com sua concepção do espetáculo trágico grego - de uma unidade em ato entre o povo/comunidade e o belo artístico, que seria a mais alta realização da cultura ou do espírito. Este último que, ao longo da história da separação se dividira entre religião, filosofia, Estado e ciência, estaria por realizar-se como retorno desses saberes diversos e, por isso, falsos

\footnotetext{
${ }^{4}$ Note-se que esse esquema da impotência temporária da necessidade para efetuar a passagem transformadora sustentava seu cômputo da história e do destino da tragédia, na Grécia. Na tragédia, o espírito do povo teria feito ampliar o espaço político, com a inclusão de artesãos e mercadores na pólis, o que desatou um movimento pela escravidão universal, no que era, enfim, o caminho da revolução da humanidade a acumular miséria e luxo, até que a necessidade viesse a desatar o reaprumo revolucionário.

${ }^{5}$ É um crime político usar esse termo. Contudo, nenhum outro descreve tão bem a antítese ao egoísmo. Quem, nos dias de hoje, se envergonha do egoísmo, e de fato ninguém se confessa abertamente um egoísta, deve nos conceder a liberdade de chamá-lo comunista. Esta é uma nota de rodapé do próprio autor (WAGNER, 1892b, p. 167).
} 
ou imperfeitos, a uma apreensão total e imediata do tipo que acreditava ter sido a tragédia grega, aliás, a única realização da unidade do espírito humano já vista na história, malgrado sua estreiteza. Tal postulado de uma origem comum de todas as formas do saber e de sua futura união ou síntese na arte, na Gesamtkunstwerk, requer alguma explicação sobre a epistemologia de Wagner.

O conhecimento verdadeiro, o compositor o concebia como a apreensão de fenômenos físicos em sua atualidade: dito de outra forma, o conhecimento partiria da percepção sensória e chegaria a uma representação que retivesse a coerência necessária da realidade física. ${ }^{6}$ Essa coerência, da qual a verdade do conhecimento dependia, confluiria para "o que é atual na completa e acabada manifestação para os sentidos"; esse conhecimento reconheceria sua própria possibilidade como "condicionada a priori pela atualidade". Assim, o descaminho do pensamento seria abstrair da atualidade, pelo que resvalaria para a fantasia, "a qual se separa forçosamente do inconsciente" (WAGNER, 1892b, p. 80), ou da natureza. O pensamento poderia reivindicar algo da energia do "inconsciente", da necessidade enquanto força vital, somente enquanto pudesse "perscrutar a fisicalidade e deitar um olhar simpático às profundezas de uma necessidade física atual” (WAGNER,1892b, p. 80). Assim, o conhecimento objetivo verdadeiro, que Wagner acusava de parcial e arrogante, terminaria por ser assimilado à simpatia ou consonância com uma força vital ou, de outra maneira, o conhecimento científico seria reassimilado a uma contemplação quase mística. Desse modo, a ciência e a técnica modernas estariam destinadas a retornar ao físico imediato, enquanto necessidade ou princípio vital tornado consciente numa humanidade realizada, a qual viria entáo a exercitar de forma ilimitada a sua faculdade de apreensão imediata.

A propósito, convém lembrar que o desejo de comunicação direta e imediata da arte, bem como a acusaçáo hegeliana de que a arte se teria tornado dependente da mediação das ideias, já se tornou, há muito, um lugar comum entre autores e proposiçóes. No entanto, a hipostasia do físico-atual por Wagner revela talvez uma suspeita para com a reflexão: que esta fosse um mal necessário, que teria a finalidade de preparar sua própria futura dissolução. A carência sentida do modo mais imediato, como fome ou sede, por exemplo, identificava-se à necessidade nos fenômenos físicos, ou seja, a carência do povo seria verdadeira e a reflexáo um luxo do espírito, cuja aparente necessidade seria apenas temporária. $\mathrm{O}$ mal necessário que era a reflexão consistiria então

\footnotetext{
${ }^{6}$ A epistemologia de Wagner é apresentada em $A$ obra de arte do futuro nos seguintes itens: capítulo I parte 4, The folk as the force conditioning the art-work, p. 79-80; capítulo I parte 5, The art-antagonistic shape of presente life, under the sway of act thought and fashion, p. 82-83.
} 
em que o pensamento, sendo o último e mais condicionado, se representasse como o primeiro e menos condicionado:

Quando isto se dá, desgoverna-se a roda da necessidade e o capricho reina cego. [...] Assim, seria como se o espírito fabricasse a natureza, como se o pensamento produzisse a atualidade fenomênica, como se o filósofo precedesse o homem. Assim, natureza, atualidade e homem não seriam mais necessários e sua existência não seria apenas supérflua, mas danosa. Pois nada há de mais supérfluo do que a permanência do incompleto quando o completo já veio a ser. [...] Se o Espírito é por si mesmo necessário, então a vida é um mero capricho, uma fantástica mascarada, um passatempo indolente, uma frívola idiossincrasia, um 'car tel est notre plaisir' do espírito (WAGNER, 1892b, p. 83).

O espírito, sendo a mais alta realização humana, era compreendido não no plano problemático da reflexáo, mas no da apreensão do nexo universal da necessidade de modo imediato por todos do povo/comunidade, como Wagner acreditava ter sido na tragédia grega e que viria a ser novamente na "obra de arte do futuro", a Gesamtkunstwerk. Assim, a faculdade superior do conhecimento, ou o espírito, seria de não somente apreender o físico-atual em todas as suas partes, mas também de perceber e representar a conexão íntima dessas partes, em sua sequência numa imagem conjunta (WAGNER, 1892b, p. 83). Não podemos deixar de notar que, se a obra de arte é a representaçáo dessa imagem conjunta da conexão na necessidade, então a obra de arte seria, a julgar pelo fraseado do compositor, como que a ideia platônica convertida em imagem, o que seria uma significativa distorçáo do platonismo de um tipo, porém, que não é estranho à história.

Levando a posição de Wagner para uma outra direção, o que se presentificava nessa representação como imagem conjunta, poderíamos, com certa latitude hermenêutica, chamar de fundamento ou razão suficiente, ou seja, algo para que a série dos entes aponta, mas que os transcende, pois ela mesma não está no plano dos entes. Essa questão que Wagner não desenvolveu mostra quão profícuo seu trabalho pode revelar-se, para estudos sobre o tema do estilo na história da arte e da arquitetura, em conexão com seu viés especulativo.

Mas o que é este que transcende? Segundo possamos compreender, no pensamento de Wagner, seria a vida mesma, ou seja, a necessidade em ato. Curiosamente, o que no formato da razão suficiente seria metafísico se deslocava para o próprio físico. Com Wagner, a transcendência, ou melhor, a 
teleologia, se cumpria na atualidade e na fisicalidade imediata, na satisfação da necessidade sentida no corpo, tal era sua paradoxal localização do metafísico, na necessidade física mesma.

Posto, porém, de outra forma, a apreensão da totalidade humana segundo o nexo universal da necessidade seria o povo, totalidade numérica humana ou, pelo menos, a maioria enquanto a totalidade daqueles que reconheçam sua necessidade como coletiva. Essa representação da totalidade conexa seria a boa coerência, o oposto do que o compositor chamava de "má coerência que sustenta as condiçôes do jugo antinatural" (WAGNER, 1892b, p. 81), ou seja, aquela que provém de abstrair da atualidade física imediata e de pôr-se como anterior à mesma:

Então, [...] a felicidade do homem [povo] torna-se secundária, e o Estado abstrato passa a ser a consideração principal, enquanto que o povo tornase acidental, bem como o príncipe e o sábio tornam-se os consumidores necessários deste último (WAGNER, 1892b, p. 84).

Essas passagens um tanto intrincadas têm como resultado, entre outros, não somente reconduzir ciência e contemplação mística, filosofia e Estado à Gesamtkunstwerk, mas também dar à ideia de "povo" uma substancialidade um tanto complicada pela qual o povo passa a ser a fonte de toda a criatividade em absoluta espontaneidade:

Não os senhores ó sábios, não sois vós os verdadeiros inventores, mas o povo, pois a necessidade é o que o conduz à invençáo. Todas as invençóes são obras do povo, enquanto que as produções do intelecto nada são além de exploração, derivação e fragmentação a desfigurar as grandes invençóes do povo. Não fomos nós que inventamos a linguagem [...]. Náo inventamos o Estado, nada fizemos senão tornar a aliança natural dos igualmente necessitados na aliança perversa dos igualmente não necessitados; da benevolente liga defensiva de todos, não fizemos senão o maléfico baluarte dos poucos privilegiados. [...]. Portanto, não somos nós que deveríamos pretender ensinar o povo, mas, antes, dele tomar liçôes. Assim, é a ti que apelo e não ao povo, pois ao povo pouco há o que dizer senáo que "faça como deve fazer", o que não deixa de ser supérfluo, pois isto é o que o povo já faz. [...] O povo cumprirá sua missão redentora enquanto satisfaz a si mesmo e salva seus inimigos. [...] $\mathrm{O}$ povo só precisa fazer do não desejável o não existente $\mathrm{e}$, por força de sua própria carência, aniquilar o que não é digno senáo de aniquilação. Desse modo, o que se deseja do futuro insondável mostrar-se-á de pronto por si mesmo (WAGNER, 1892b, p. 80-81). 
Ora, não podemos deixar de notar aqui as falhas gerais de todo populismo, tão frequentes nas ideologias que acompanharam os processos de formação tardia dos Estados nacionais, como era o caso da Alemanha de 1848-1849 até 1870 e como tem sido até nossos dias, em amplas partes do globo. Pensar o povo como a agir por natureza faz dele uma ficção do agir e viver sem angústia, sem ter que haver-se com a liberdade, ainda que finita ou condicionada. Essa concepçáo substantiva do povo nos parece inadvertidamente ambígua ou autocontraditória, visto que toda criatividade era atribuída ao povo. Como seria possível criar artisticamente ou de qualquer modo, sem calar, por um instante que fosse, a voz da necessidade? Essa concepção, à medida que é evocada para legitimar projetos políticos, requer o concurso de "intérpretes" do povo que digam o que ele é ou não é7; e foi o que Wagner fez com o seu Was ist Deutsch? (O que é o alemão?) (VICHI; RICON, 2011), escrito em 1865 e revisado em 1878.

Nesse texto de propaganda em prol da unificação alemã, em versão conservadora, Wagner punha-se a definir o que fosse o traço peculiar de sua nacionalidade: o "caráter nacional" alemão. Mas, de saída, confessava enorme dificuldade em encontrar qualquer coisa que singularizasse sua nacionalidade, pelo que concluía por aquilo que, no idioma alemáo, é chamado de "cultura" por oposição a "civilização". Essas palavras que, em outras línguas, são intercambiadas sem dificuldade, no idioma alemão (MOURA, 2009) tornaram-se indicativas de uma diferença ética, ou seja, entre a "civilização" dos costumes nas cortes dos principados, que seguiam o padrão da corte francesa desde Luís XIV, e a "cultura", entendida como grandeza intelectual ou artística, atingida pelo intenso afinco e operosidade, como marca distintiva de seu povo.

Assim, em defesa dessa construção da nacionalidade, Wagner fazia do gênio de Bach, que afinal passara a vida como um operoso serviçal de cortes periféricas alemãs, um símbolo da "cultura" contra a opressão da "civilização". Observe-se que essa seriedade ou operosidade em prol do belo, livre do interesse material e egoísta do ganho, era uma certa ética do trabalho, talvez mais beneditina do que protestante, mas uma ética e não uma diferença racial. Infelizmente, a noção de "caráter nacional" resvala para o biológico (CHAUÍ, 2001, p. 10-12), para uma comunidade consanguínea, o que - de

\footnotetext{
${ }^{7}$ Numa teoria política democrática, assim pensamos, o povo comparece apenas como uma hipótese formal, a partir da qual se pode desenhar regras e instituiçôes, sem que se tenha de saber, como se fosse um conceito, o que o povo é ou queira. A vontade do povo passa a ser, entáo, o resultado dos procedimentos, mas sempre de forma bem pontual e como marco de um corpo político.
} 
modo implícito ou explícito - tem sido um apelo presente nos movimentos nacionalistas desde o séc. XIX. Infelizmente, e com uma irresponsabilidade política funesta, Wagner veio a defender a nacionalidade operosa pela cultura para além do interesse do ganho contra seus supostos inimigos de "sangue", principalmente os judeus e sua caricatural sede de ganho materialista e de poder pela usura.

\section{A DÉMARCHE HISTÓRICO-FILOSÓFICA DA GESAMTKUNSTWERK}

A exemplo de tantos pensadores oitocentistas, Wagner elaborou uma história especulativa e um sistema das artes, bem como uma construção consoante do sentido último e do destino de cada uma delas. Seu conceito de arte radicava no mesmo âmbito que o de seus predecessores, no campo idealista: arte como representaçáo sensível do suprassensível, todavia, tinha sua própria concepção do que fosse o suprassensível, a saber, a boa coerência ou a apreensão do nexo da necessidade, como vimos anteriormente. Por conseguinte, seu sistema exigia o encontro entre a essência e o ato, o que náo se daria nos começos imperfeitos, mas em um cume de seu desenvolvimento, como na tragédia grega.

Esses escritos wagnerianos são, não esqueçamos, obra de um artista e apresentam seu "programa estético", o qual é de se esperar tenha determinado, de uma maneira ou de outra, sua obra musical e operística. Contudo, suas formulaçôes fizeram-se sentir também na constituição da disciplina da história da arte, incluída a da arquitetura, por obra de Gottfried Semper, em particular, e até mesmo em programas das vanguardas artísticas do séc. XX.

Em seu sistema das artes, o desenvolvimento da escultura, dentre outras, é particularmente simples e claro, de sorte a permitir-nos um vislumbre abreviado do plano histórico-filosófico da Gesamtkunstwerk, além de flagrar alguns aspectos das relaçóes com outras artes. Na escultura, cujo futuro desenvolvimento procurou perscrutar, destacou o antropomorfismo de um modo que nos parece ter repercutido mais na teoria da arquitetura e, provavelmente, na forma como Gottfried Semper concebeu a relação entre a arquitetura e as demais artes, através do estilo, ou seja, aquele regime do sentido comum entre todas as artes, cuja ausência foi sentida no séc. XIX, de modo mais dramático pela arquitetura (HVATTUM, 2013). 
Para sua história conjectural da escultura, Wagner construía o surgimento da arte no âmbito da religiáo e do mito, entretanto, de maneira que a arte conquistasse autonomia, na proporção que crescia a autoestima humana. Assim, as primeiras agregaçôes humanas teriam sido obras da natureza e constituiriam laços de descendência comum, os quais viriam a ser representados nas várias religióes. Porém, sendo a essência em ato, o homem só poderia figurar o invisível com a matéria de sua própria imagem, mesmo que deformada em suas proporçóes ou misturada com as formas de animais. Quanto maior a autoestima humana, tâo mais perfeitamente os deuses se deixavam representar pela bela forma humana, no que a diferença entre gregos e asiáticos se explicitava na estatuária e nos ídolos. Autoestima humana significava o modo e o lugar ocupado pelo homem, em face da natureza extra-humana e dos deuses invisíveis, um lugar muito diferente para gregos e asiáticos.

Os gregos, enquanto povo, “[...] conferiram solenidade à celebração da ancestralidade comum em seus banquetes religiosos, a saber, na glorificação e na adoração do deus ou do herói em cujo ser sentiam-se pertencentes como se fossem todos um só" (WAGNER,1892b, p. 166). Por fim, para fixar e rememorar suas tradiçóes, que já iam se perdendo no tempo, criaram a mais alta forma artística, a tragédia. Mesmo assim, a tragédia já era ou anunciava um ponto de inflexão:

As obras de arte dramáticas eram atos religiosos. Mas já havia nestes atos, se comparados aos ritos religiosos mais simples, algo de um esforço artificial, em propositalmente realçar a memória comum que já ia perdendo a impressão viva no cotidiano. Desse modo, a tragédia era a conversão à obra de arte daquele rito original cuja interioridade ia já se perdendo, ao ponto de converter-se em cerimônia convencional e vazia. $\mathrm{O}$ que originalmente estivera no âmago do rito religioso passava a viver na obra de arte (WAGNER, 1892b, p. 165).

Entre religião, mito e arte haveria uma relação pela qual a arte, de instrumento auxiliar, passara a uma atividade independente, capaz, a seu modo, de tornar visível o invisível, ou de reencenar para a comunidade, ou de dar vida mais uma vez, a sua experiência fundadora com a necessidade. Em sua primeira perfeição, com os gregos clássicos, contudo, a arte já ia mostrando algo de rememoração de uma verdade já passada na religião e no mito. Semper fez dessa rememoração ou reencenação o fator constitutivo mesmo da força da arte, quer dizer, o estilo; o que este último reencenaria, 
no entanto, era determinado como as experiências fundadoras da construção do abrigo humano ou da luta da espécie pela sobrevivência, o que Semper (1989b) formalizava nos "quatro elementos da arquitetura" e nas técnicas correspondentes. A visada historiográfica e não especulativa desse autor se mostrava em que a evocação daquela experiência tinha que se haver com as mudanças de técnicas e com as inúmeras mudanças políticas e geográficas na constituição dos povos. Desvendar essas mudanças que permitiam reenviar dos símbolos arquitetônicos aos quatro elementos foi boa parte de seu monumental Estilo nas artes técnicas e tectônicas (2004).

Por outro lado, aquela rememoração pela arte era uma experiência constitutiva do ethos ou do povo mesmo, sem a qual a arte se afastaria dele, se tornaria luxo das elites e reinaria a fealdade que Wagner e Semper (2004, p. 83-92) viam por toda parte, no mundo moderno. Esse aspecto da rememoração viria a constituir as teorias semperianas dos "determinantes formais do belo", do "regente coral" das formas (SEMPER, 1989b, p. 52) e da monumentalidade, pelo que esta última se tornaria um tema da história da arte com um discípulo de Semper, o historiador da arte Aloïs Riegl, e sua elaboração do "culto moderno aos monumentos", e com Giedion e sua concepção de arquitetura obra de arte enquanto plasmadora dos monumentos da comunidade (GIEDION; SERT; LÉGER, 1993, p. 29-30).

Apesar disso, é bom que se perceba a ambiguidade que há na concepção wagneriana do monumento. Numa certa passagem na qual escrevia que a força vital "retira-se da exclusividade, da singularidade monumental que ela havia até então nutrido, e resolve-se em multiplicidade" (WAGNER, 1892b, p. 78), representava o egoísmo como a "singularidade monumental" ou a "exclusividade", ambos como opostos à abundância e à multiplicidade da força vital.

Em Wagner, o processo de encenação religiosa dos mitos e divindades representantes da origem do povo reservou um papel especial à exteriorização da religião nos paramentos sacerdotais, os quais teriam evoluído aos figurinos cênicos no teatro: "Sob este traje, o ator trágico incorporava a figura reverenciada em comum, o laço de união original [...] O coturno e a máscara e outras marcas simbólicas primeiro conferiram ao ator o caráter substantivo do sacerdote." (WAGNER, 1892b, p. 165). Semper (2004, p. 247-50, p. 438439) derivaria dessa interpretação da vestimenta sacerdotal, profundamente envolvida na constituição da comunidade na experiência originária com a necessidade, a noção positiva, não irônica, da ornamentação arquitetônica 
como uma vestimenta (Bekleidung) da estrutura, algo constitutivo da simbolizaçáo, a qual, originária da técnica da tecelagem, se teria depositado nas formas consagradas do estilo.

\section{ARTE: DECADÊNCIA DA RELIGIÁO. ARTE: DECADÊNCIA DA ARTE}

O aparecimento do corpo humano nu na escultura e no teatro clássicos se teria dado por despir-se a representaçáo do homem do manto religioso, o que marcaria o momento em que o centro da religião grega, desfazendo-se de seu último disfarce, se revelava como o homem mesmo, "o centro ao redor do qual tudo revolvia e que instintivamente afirmava seu domínio exclusivo na vida" (WAGNER, 1892b, p. 166). Nesse sentido, o corpo representava em Wagner o papel da fisicalidade imediata no comércio entre o sensível e o suprassensível, pelo que a escultura, ou melhor, a estatuária, podia representar (1892b, p. 172) mais do que qualquer outra arte, a beleza do corpo humano, de forma que propiciasse um caminho às paixóes superiores, ou seja, da beleza dos corpos à beleza das leis, como no amor de Afrodite Urânia, em Platáo (1979, p. 40-43). A escultura tornava sensível uma dimensão política, a saber, o belo e o bem comum unidos no amor de Afrodite Urânia:

$\mathrm{O}$ ponto alto daquele amor grego de homem para com homem consistia nisto: em purgar o egoísmo do desejo físico. Não obstante, não somente incluía o laço espiritual puro da amizade, como esta era a flor do amor físico. Este último brotava diretamente do deleite no belo, na beleza corpórea e material do amado camarada. Contudo, este deleite não era desejo egoísta, mas um completo abandono de si mesmo numa simpatia sem reservas para com a alegria do companheiro consigo mesmo, que este traía sem querer em sua alegria de viver sob o impulso do belo (WAGNER, 1892b, p. 168).

Vale a pena observar que a escultura, ou estatuária, operava, com Wagner, uma espécie de rememoração ou de encenação de segunda ordem, não mais da experiência originária da comunidade, mas do drama trágico, o qual realmente era uma reencenaçáo daquela, no momento da plenitude de seu significado. $\mathrm{O}$ desenvolvimento dessa reencenação segunda seria, em verdade, sintomático da decadência do mundo helênico, subsequentemente, da tragédia, movimento este pelo qual o paradoxal rebento do homem pleno grego viera a ser o egoísta moderno: 
Assim como Esparta se elevava como monumento vivo aos velhos tempos [trágicos], a arte da escultura [ou estatuária] cristalizou na pedra o velho tipo humano helênico que ela, assim, reconhecia como monumento vivo e com ele guarneceu o monumento frio da beleza perdida para os tempos porvir de crescente barbarismo. (1892b, p. 169) [...] A arte que fez deste homem nu, solitário e egoísta, o ponto de partida mesmo do período assim chamado de história universal, e o exibiu diante de nós como belo monumento de advertência foi a arte da escultura, a qual atingiu seu máximo exatamente na época em que a obra conjunta da tragédia declinou (1892b, p. 167) [...]. O desvanecimento gradual da beleza humana da existência em ato, foi a primeira causa do desenvolvimento artístico da escultura (WAGNER,1892b, p. 171).

Aquela secularização da religião, pela qual o invisível se revelava no vivente em ato, representou, paradoxalmente, segundo o compositor, a quebra do laço comunitário que se tornou insustentável em face da autonomia individual, a qual, por sua vez, era incompatível com a representação religiosa, pois nenhum indivíduo poderia representar o invisível:

Este é o homem, adorável em sua pessoa, porém muito menos em seu isolamento egoísta, que a arte da escultura nos legou em mármore e bronze, imóvel e frio, como que uma lembrança petrificada, como que a múmia do mundo grego (WAGNER, 1892b, p. 170).

Era como se o mundo helênico, afinal, uma comunidade de livres contra escravos, não suportasse tal secularização, a qual teria sua religação à comunidade, agora concebida como universal, posta como finalidade da futura "revolução da humanidade". Na época em que se dera, no entanto, fora o fim da comunhão que a tragédia ainda realizava, supostamente:

Daí por diante, com a dissoluçấo da religião grega, com a ruína do Estado-natureza grego, e sua assimilaçáo ao Estado político, com o desmembramento da obra trágica comum, a humanidade da história universal começa sua marcha evolutiva colossal, da queda do parentesco natural e da comunidade nacional à camaradagem universal de toda a humanidade. O laço que o homem pleno rompeu, pois, coleira sufocante, ao tomar consciência no âmbito nacional helênico, deveria então estenderse a toda a humanidade. O período até nossos dias tem sido a história do absoluto egoísmo, período este cujo fim será a redençáo no comunismo (WAGNER, 1892b, p. 166-167). 
Repare-se, nesse fraseado de Wagner, como o belo e o bem comum "naturais", pela força do mito e da religião étnica, sustentavam o "Estado natural" contra o "Estado político", o que não nos surpreende em face da hipostasia do povo, em detrimento da política. Assim como tantos críticos da cultura oitocentistas, Wagner desprezava o "Estado político", no qual o elo entre os homens seria reduzido ao interesse egoísta e à forma da lei. Essa composição de contradições perfaz uma dialética histórica diversa daquelas de Hegel e de Marx, porém, que confiava ao desenvolvimento material da técnica e da indústria a realização da condição de possibilidade da comunidade universal ou o "comunismo". Não admira que essa ideologia Vormärz tenha sido escrita simultaneamente e no decorrer de um mesmo processo político que o Manifesto Comunista.

Essa mesma dialética explicava que a escultura, entendida como estatuária, derivava sua relativa necessidade da ocorrência já passada de uma vida humana bela, a grega. Se, na Idade Média, ainda havia alguma necessidade no mármore e no bronze, com a modernidade e a exteriorizaçáo do homem egoísta pleno, ela tornou-se muito menos que pura rememoração, senão imitação ad infinitum ou "plágio de uma arte genuína", convertida em ofício comercial apoiado em regras e cânones sem fim:

A escultura moderna pode ainda responder a algum vestígio de necessidade enquanto o adorável homem continuar ausente da vida de nosso tempo. Mas a ressurreição de sua beleza terá como consequência imediata na fatura da vida, o fim da plástica atual. [...] o verdadeiro anseio criativo procede da plenitude e não do vazio: enquanto a plenitude da escultura moderna é meramente o inventário de monumentos que nos legaram as artes plásticas da Grécia (WAGNER, 1892b, p. 172).

Os monumentos escultóricos operariam uma rememoração de segunda ordem, que seria rememoração permanente da ausência, de um desapossamento ou separação que só seriam suprassumidos, se o impulso do escultor reencontrasse na vida a presença atual física do belo corpo:

O desencantamento da pedra na carne e no sangue do homem; [...] da imobilidade ao movimento; do monumental ao temporal. [...] que o impulso do escultor passe para a alma do dançarino [...], este performer mimético que também fala e canta (WAGNER, 1892b, p. 73).

\footnotetext{
${ }^{8}$ Essa expressão, que significa literalmente "pré-março", refere-se ao que fosse próprio ao período anterior às revoluçōes que tiveram início em março de 1848, na Alemanha.
} 
O ideal de um encontro entre a arte e a vida mostra-se, no extremo, como um horror à coisificação, como um horror teológico a ídolos, horror à materialidade monumental da obra, como se esta aprisionasse e congelasse a alma ou a vida. Esse é o lugar extremo que o corpo viria um dia a ocupar para a arte? .

Por outro lado, a obra de arte total não deixa de parecer-nos mais uma exigência extrema da moral autonomizada, a qual clama pela vida bela ou pelo belo na vida em ato, do que propriamente artística. Ou, talvez, fosse um momento em que as artes enfrentassem dificuldades tais, que, mais tarde, as levariam ao extremo de ensaiar sua autossupressão, para melhor competir ou curvar-se à moral todo-poderosa. No seu tempo, contudo, Wagner propunha o fim da escultura como "arte independente", com o abandono da convenção da estatuária e sua integração à arquitetura.

Aqui, deparamo-nos com duas questôes muito reveladoras. Primeiro, a arte hipostasiada como força propulsora histórica, ou simplesmente revolucionária, trazia consigo um ônus a ser pago, no limite, com a negaçáo da autonomia da arte; e essa nota promissória poderia ser cobrada a qualquer momento. Segundo, determinar especulativamente as possibilidades futuras de um gênero era um empreendimento especulativo destinado a ser menos profético do que revelador sobre o profeta. O desenvolvimento da escultura moderna, mais tarde, ou reconstruiu a estatuária completamente ou se desfez dela totalmente, importando antes que a escultura fosse capaz de criar uma espacialidade própria, o que não significa necessariamente conflito com a arquitetura, mas algo diverso de toda a tradição em que as duas artes se associavam até então.

Note-se, também, que o surto do corpo humano nu na escultura e na dança, mas com analogias outras, veio a estar presente na teoria semperiana dos "determinantes formais do belo" (SEMPER, 2004, p. 83-92), os quais desempenhavam como uma representação primordial e universal da experiência da hominização, em face da necessidade, de modo a projetar-se em toda concepção de forma e de espaço. Essa teoria exerceria uma sensível influência em historiadores como August Schmarsow, além de ter dado sugestôes fundamentais para vanguardas, como De Stijl e o Purismo de Le Corbusier.

\footnotetext{
9 Não admira, portanto, que algumas vanguardas tenham pretendido uma desmaterializaçấo da arte, como o escultor Joseph Beuys $(1921,1986)$, que dizia que "pensamento é escultura" e que apresentava peças as quais já não eram esculturas, mas um registro ou vestígio de uma performance, esta sim, de plena atualidade, de pleno reapossamento.
} 


\section{CONSIDERAÇÓES FINAIS}

O destino do envolvimento de Wagner com políticas nacionalistas e populistas, na época da unificação alemã e ainda mais tarde, políticas estas que formaram o caldo de cultura no qual surgiu o nazismo, tem há muito comprometido a compreensão de sua obra como pensador, a doutrina da Gesamtkunstwerk. No entanto, aqui e ali, na historiografia da arte e da arquitetura modernas, deparamos com referências de autores e personalidades a Wagner, num quadro que já se tornou, para o público mais amplo, um hiato historiográfico, daí a oportunidade em ir mais uma vez a seus originais de cunho especulativo.

Cremos ter acertado em fazer compreender a Gesamtkunstwerk no contexto do ceticismo hegeliano para com o destino da arte, na modernidade, o que vimos chamando de mal-estar com a arte. Wagner como que reagia ao prognóstico hegeliano com esperanças de uma revolução estética e políticosocial, espelhada em sua construção da tragédia grega como a obra da cooperação entre as várias artes e de plena identidade com a comunidade da pólis. A arte seria, para Wagner, a forma de conhecimento que identificaria a necessidade sentida no corpo com a apreensão da necessidade nos fenômenos os mais recônditos. Essa identidade propiciaria, mais uma vez, a unidade da arte, ou da Gesamtkunstwerk, com o público e a uniâo na arte de todos os saberes até então mutuamente opostos; a obra de arte total seria, por conseguinte, a reencenação da experiência originária com a necessidade para além de todo velamento e esquecimento que se lhe encrustaram, no seu devir.

O mal-estar com a arte, na modernidade, foi compreendido de vários modos. Hegel via a arte dependente da mediação de ideias abstratas, pois também o coração dos homens havia se tornado frio para as imagens. Wagner via a arte como sucedâneo da religião e do mito a ter recuperado para a experiência estética na Grécia o que já se perdia para a religiáo e para o mito. De qualquer modo, formulava o universalismo nos termos tão peculiares como compreendia retrospectivamente a participação popular, no espetáculo trágico helênico, o mesmo universalismo que acreditava, na modernidade, ter a revolução universal ao alcance da mão, graças ao poder produtivo da indústria moderna, científica e capitalista. Nesse contexto, a obra de arte total plasmaria a comunidade numa experiência que não diminuísse a ambição estética.

Essa esperança na cooperação entre os gêneros artísticos era sob medida para as concepçóes da ausência do estilo na modernidade, sensíveis em alguns 
campos da cultura, em particular na arquitetura. O estilo concretizava, em outras épocas, uma unidade de sentido entre as diversas artes, como se a metafísica se manifestasse através das artes. A Gesamtkunstwerk oferecia uma narrativa da diáspora entre as artes egoístas e da correção desse curso histórico, pelo que se repunha a unidade do estilo. Não é de admirar que o discurso de Wagner tenha encontrado ressonância no debate arquitetônico oitocentista em torno da criação do estilo da modernidade, o que se deu com a teoria do estilo de Gottfried Semper. Este último autor, talvez, tenha sido mais importante mesmo para as nascentes teorias da história da arte, através de Schmasow e de Riegl.

GABRIEL, M. F. From total work of art to the synthesis of arts. Trans/form/ação, Marília, v. 43, n. 2, p. 189-214, Abr./Jun., 2020.

\begin{abstract}
There had been througout the 20th century a persistent recurrence of the theme of the synthesis or integration of arts, in the field of architecture at least. It was present amongst the early twentieth century vanguards but had a bounce back in the early postwar period with Le Corbusier, Sigfried Giedion and Fernand Léger. In Brazil in the 1950s, art critic Mário Pedrosa under the mote Brasilia enthusiastically hailed the construction of Brasília the New City, Synthesis of Arts (1981b, p. 355-363). The corresponding literature points out to architect and historian Gottfried Semper, a nineteenth century theorist of style, who cooperated closely with composer and operist Richard Wagner as the authors who put forth the original conceptions of the Gesamtkunstwerk or total artwork. In this study, we examine the speculative guise with which Wagner held up the Gesamtkunstwerk, as a strategic step for the studies on the theme.
\end{abstract}

KEYwORDS: Gesamtkunstwerk. Synthesis of arts. Integration of arts. Architectural theory. Historical avant-garde.

\title{
REFERÊNCIAS
}

ARENDT, $H$. The crisis in culture: its social and its political significance. In: ARENDT, H. Between past and future. Nova York: Penguin Books, 1977. p. 194-222.

ARENDT, H. A condição humana. São Paulo: Editora Forense Universitária, 1999.

BANHAM, R. Theory and design in the first machine age. New York: Praeger Publishers, 1970.

CHAUÍ, M. Brasil, Mito Fundador e Sociedade Autoritária. São Paulo: Fund.Perseu Abramo, 2001. 
GIEDION, S.; SERT, J. L.; LÉGER, F. Nine points on monumentality. In: OACKMAN, J. (Org.). Architecture culture 1943-1968. New York: Columbia Books of Architecture/ Rizzoli, 1993. p. 29-30.

GIEDION, S. The need for a new monumentality. In: ZUCKER, P. (Org.) New architecture and city planning. New York: Philosophical Library, 1944. p. 549-568.

HEGEL, G. W. F. Curso de Estética - o belo na arte. São Paulo: Martins Fontes, 1996. p. $19,25-26$.

HVATTUM, M. Crisis and correspondence: style in the 19th century. 2013.

Architectural Histories, 1(1):21. P. 1-8, DOI: http//dx.doi.org/10.5334/ah.an. Disponível em <HTTPS://brage.bibsys.no/xmlui/handle/11250/182920> Acesso em: 15 set. 2015.

LE CORBUSIER. Vers Une Architecture. Paris: Les Editions George Crès \& Cie, 1923.

LE CORBUSIER. Urbanisme. Paris: Les Editions George Crès \& Cie, 1924.

MALLGRAVE, H, F. e HERRMANN, W. (Orgs.) The four elements of architecture and other writings. Cambridge: Cambridge University Press, 1989.

MOURA, C. O advento dos conceitos de cultura e civilização: sua importância para a consolidação da autoimagem do sujeito moderno. Filosofia Unisinos, v. 10, n. 2, p. 157173, maio/ago. 2009. Disponível em: <http://doi.org/10.4013/fsu.2009.102.03>. Acesso em: 25 out. 2016.

PEDROSA, M. Arquitetura e crítica de arte -I. In: AMARAL, A. (org.). Dos Murais de Portinari aos Espaços de Brasília. São Paulo: Perspectiva, 1981a. p. 269-271.

PEDrOSA, M. A Cidade Nova, Síntese das Artes. In: AMARAL, A. (Org.). Dos Murais de Portinari aos Espaços de Brasília. São Paulo: Perspectiva, 1981b. p. 355-363.

PEDROSA, M. Fundamentos da arte abstrata (1953). In: PEDROSA, M. Dimensóes da arte. Rio de Janeiro: Ministério da Educação e Cultura, 1964. p. 207-215.

PEDROSA, M. Da Abstração à auto expressão (1959). In: AMARAL, A. (Org). Mario Pedrosa - mundo em crise, homem em crise, arte em crise. São Paulo: Perspectiva, 1975. p. 35-47.

PLATÃO, O banquete. In: Pessanha, J. A. M. (Org.) Platáo. São Paulo: Abril Cultural, Coleção os Pensadores, 1979.

RANCIÈRE, J. O espectador emancipado. São Paulo: Editora WMF, 2012.

SEMPER, G. Style in the technical and tectonic arts; or, practical aesthetics. Los Angeles: Getty Research Institute, 2004.

SEMPER, G. Preliminary remarks on polychrome architecture and sculpture in antiquity. In: MALLGRAVE, H, F.; HERRMANN, W. (Orgs.) The four elements of architecture and other writings. Cambridge: Cambridge University Press, 1989a. p. 45-73. 
SEMPER, G. The four elements of architecture. In: MALLGRAVE, H, F.;

HERRMANN, W. (Orgs.) The four elements of architecture and other writings.

Cambridge: Cambridge University Press, 1989b. p. 74-129.

VICHI, L. P.; RICON, L. C. C. Para o despertar de uma natureza germânica: o texto Was Ist Deutsch? De Richard Wagner. Veredas da História, v. 4, n. 1, 2011. Disponível em: <http://www.seer.veredasdahistoria.com.br/ojs-2.4.8/index.php/veredasdahistoria/ article/view/60/63>. Acesso em: 18 dez. 2015.

WAGNER, R. Art and revolution. In: WAGNER, R. Richard Wagner's prose works. London: Kegan Paul, Trench, Trübner \& co., Ltd. 1892a. p. 30-65.

WAGNER, R. The art-work of the future. In: Richard Wagner's prose works. London: Kegan Paul, Trench, Trübner \& co., Ltd. 1892b. p. 69-213.

Recebido: 31/10/2018

Aceito: 26/4/2019 